MANNHEIM RESEARCH INSTITUTE FOR THE ECONOMICS OF AGING

\title{
Changes in Compulsory Schooling and the Causal EfFEct of Education ON HEALTH: EVIDENCE FROM GERMANY?
}

Daniel Kemptner, Hendrik Jürges, Steffen Reinhold 


\title{
Changes in Compulsory Schooling and the Causal Effect of Education on Health: Evidence from Germany
}

\author{
Daniel Kemptner ${ }^{\S}$, Hendrik Jürges ${ }^{\#}$, and Steffen Reinhold*
}

June 08,2010

\begin{abstract}
$\underline{\text { Abstract }}$
In this paper we investigate the causal effect of years of schooling on health and health-related behavior in West Germany. We apply an instrumental variables approach using as natural experiments several changes in compulsory schooling laws between 1949 and 1969. These law changes generate exogenous variation in years of schooling both across states and over time. We find evidence for a strong and significant causal effect of years of schooling on long-term illness for men but not for women. Moreover, we provide somewhat weaker evidence of a causal effect of education on the likelihood of having weight problems for both sexes. On the other hand, we find little evidence for a causal effect of education on smoking behavior. Overall, our estimates suggest significant non-monetary returns to education with respect to health outcomes and not necessarily with respect to health-related behavior.
\end{abstract}

Keywords: School reform, Health, Obesity, Smoking, Instrumental Variables

JEL-Codes: I12, I21

Acknowledgements: We are grateful to Michael Lechner, participants at the Annual Meeting of the Committee on Population Economics 2010 of the German Economic Association (VfS), and our colleagues Eberhard Kruk and Stefan Listl for helpful comments.

\footnotetext{
${ }^{\S}$ DIW Berlin, Graduate Center, Mohrenstr. 58, 10117 Berlin, Germany. Email: dkemptner@diw.de

\# MEA University of Mannheim, L13, 17, 68131 Mannheim, Germany. Email: juerges@mea.uni-mannbeim.de

* MEA University of Mannheim, L13, 17, 68131 Mannheim, Germany. Email: reinhold@mea.uni-mannbeim.de
} 


\section{Introduction}

One of the most robust findings in both the economic and medical literature is the positive association between education and health (e.g. see the survey articles by Cutler \& Lleras-Muney 2008 or Grossman 2006). This relationship can be found in many countries, at different education levels and for various indicators of health. In fact, the relationship between education or socio-economic status in a wider sense and health is so ubiquitous that is often simply referred to as "the" gradient (Deaton 2003). However, the association between education and health behavior does not necessarily reflect a causal effect of education on health and there is now a lively debate, especially in the economics literature, whether this association (or how much of it) is causal.

This discussion is highly policy-relevant because, among the components of socioeconomic status (education, income, and occupation), education seems to be the one that - in the long run - appears to be most amenable to public policy interventions. Moreover, as noted by Deaton (2002), it is important to frame social policy in terms of health and wealth simultaneously. Improving one at the expense of the other involves a difficult and probably unnecessary trade-off. One possible policy instrument for improving health and wealth simultaneously is education. If education improves both wealth and health, giving people access to more and better education will - in the long run - be a more successful policy than redistributing income or expanding public health care expenditures.

The question is thus: does education improve health? One theoretical explanation why more education might causally lead to better health is that education raises an individual's efficiency in health production, i.e. education raises the marginal productivity of inputs into health production (Grossman 1972). Just like more educated people are more productive in labor market activities they are likely to be more productive in non-market activities, which include the production of their own health (or the health of their children). Better educated people would thus be healthier even if inputs were held fixed.

Another (complementary) theoretical explanation is that education changes the inputs into health production (through information) and thereby increases allocative efficiency. Most prominently, education might change health behaviors such as smoking or bad nutrition habits (Rosenzweig \& Schulz 1981, Cutler \& Lleras-Muney 2010). It has been shown that education is associated with substantially reduced smoking and obesity rates, two important causes of premature deaths (Mokdad et al. 2004). For example, smoking rates in Germany are 48\% among less educated men, as opposed to $20 \%$ among men with college degrees (Deutsches 
Krebsforschungszentrum 2004). Education might improve health behaviors for several reasons. First, better educated people might be better informed about negative health consequences of smoking and overeating, either because they learned about these consequences in school, or because better educated people find it easier to obtain and evaluate such information (Kenkel 1991, Nayga 2000, de Walque 2007). Second, education could also influence health behavior through higher income, different social environments, a different sense of control, or an impact of education on time preferences, e.g. because schooling focuses students' attention on the future (Fuchs 1982, Becker \& Mulligan 1997).

Despite many convincing arguments why there should be a causal effect of formal education on health, concerns about an interpretation of correlations as causal relationships remain. Most importantly, unobserved heterogeneity could drive both educational attainment at younger ages and health outcomes at older ages. For instance, Carneiro et al. (2007) find strong correlations between cognitive and non-cognitive skills measured at age 11 and measures of educational success such as having continued school beyond age 16 - reported at age 23 - or the highest educational qualification obtained - measured at age 43. Moreover, they find strong correlations between cognitive and non-cognitive skills measured at age 11 and the probability of smoking at age 16 (measured at age 16), and self-assessed health, depression and mental health problems in adulthood (all measured at age 42). This is evidence for the presence of - usually unobserved - variables driving the relationship between education and health.

The aim of the present paper is to estimate the causal effect of schooling on health exploiting variations in compulsory schooling laws in Western Germany. We follow the approach of Pischke and von Wachter $(2005,2008)$ who have used changes in years of compulsory schooling to estimate the causal effect of education on earnings. The authors found zero returns to schooling on wages. However, when estimating a reduced form regression of body mass index on the change in compulsory schooling laws they found a significant effect. Our objective is to take this line of research further and assess the nonmonetary returns of education by considering other health outcomes and also important dimensions of health-related behavior such as smoking. There is now a number of papers exploiting reforms in mandatory schooling laws across different countries, for instance the United States (Lleras-Muney 2005), the United Kingdom (Oreopolous 2006, Silles 2009, Clark \& Royer 2010), or France (Albouy \& Lequien 2008). The results of these studies are mixed, showing negative effects of education on mortality (i.e. positive effects on health) in the US (Lleras-Muney 2005) but not in France (Albouy \& Lequien 2008) or in the UK (Clark 
\& Royer 2010). In contrast, strong positive effects on self-rated health in the UK are found by Silles (2009). ${ }^{1}$ Yet further studies for the UK, assessing the effect of compulsory schooling on morbidity using objective health measures such as blood pressure, BMI, or levels of inflammatory blood markers (Clark \& Royer 2010, Jürges, Kruk \& Reinhold 2009) find no effects, while Powdhtavee (2010) finds negative effects on hypertension.

Our study extends the existing literature by analyzing compulsory schooling laws in Germany to assess the causal effect of education in yet another economic environment where the economic returns to education at the margin of the educational reform were shown to be pretty low. In addition, our paper complements earlier work on the health effect of education in (Western) Germany, using the abolition of fees in academic track schools and academic track school constructions as different sources of exogenous variation in schooling (Jürges, Reinhold \& Salm 2009, Reinhold \& Jürges 2009).

The paper is structured as follows. In the next section we will describe the German school system and the changes in compulsory schooling laws as our institutional background. Section 3 explains which data we use and shows descriptive statistics. Section 4 describes our identification strategy and its assumptions. Section 5 shows the results. Various robustness checks are reported in Section 6 and Section 7 gives a summary and discussion.

\section{Institutional Background}

In Germany, the federal states are responsible for educational policy. Still, the educational systems in all German states are very similar and thus share many common features. Children generally enter primary school at the age of six. After (normally 4 years) in primary school, students attend one of three secondary school tracks which are in most cases taught at geographically separate schools. Hauptschule is the basic track leading to a basic school leaving certificate after grade 8 or 9 . Realschule is a more demanding intermediate track which leads to a school leaving certificate after grade 10. Having finished school, both students from the basic track and the middle track usually start an apprenticeship or a school based vocational training. Gymnasium is the academic track leading to a general universityentrance diploma (Abitur) after grade 12 or 13. In addition to the three track types, some states also have comprehensive schools where all students are taught together (with internal tracking to some degree). Education in comprehensive school also leads to one of the three

\footnotetext{
${ }^{1}$ Oreopoulos (2006) reports strong positive effect on self-rated health. However, a re-analysis of the data has basically reduced this effect to zero (see revised Table 5 posted on the AER website).
} 
leaving certificates. However, this type of school is numerically unimportant for the cohorts studied in our paper. Some East German states have a middle school instead of basic track and intermediate track. Again, both types of leaving certificates are available at these schools. It is also noteworthy that, after being allocated to one of the three secondary school tracks, students rarely move between tracks, so that the track choice at the age of 10 usually has a strong implication for the entire life course (Dustmann 2004, Jürges \& Schneider 2007). The selection process itself depends on a mix of formal exams, grades in primary school, recommendations by the class teacher, and parental choice.

Since World War II, the German school system has undergone a number of reforms, among them the abolition of secondary school fees (Riphahn 2008), or the large-scale expansion of academic track schools (Jürges, Reinhold \& Salm 2009). The reform we try to exploit in the present paper is the prolonging of compulsory basic track schooling from eight to nine years. Since education policy is in the hands of state governments, this reform has taken place at different points in time. Table 1 (taken from Pischke \& von Wachter 2005) contains, by federal state, the first year when all students were supposed to stay in school for at least 9 years and the corresponding birth cohorts that were first affected by the reform. The first state to introduce a 9th grade in the basic track was Hamburg in 1949. The last state was Bavaria introducing a 9th grade in 1969. Interestingly, the data show a fairly consistent northsouth pattern, with northern states being earlier reformers than southern states. Southern states tend to be politically more conservative and have a higher proportion of Catholics. Such political and cultural differences could give rise to differences in health and health behavior as well. In our analysis, we therefore control for level differences between states and also allow for state-specific trends. Note further that in contrast to education policy, health policy is the sole responsibility of the federal government. This is important because it lends credibility to our main identifying assumption of no correlation between state trends in education and health policies. In a similar vain we argue that due to nationwide public television health information (e.g. on the hazards of smoking or obesity) should be disseminated in all states at the same time and at a similar speed.

--- about here Table 1 (school reform year and cohorts) ---

In some states, changes in compulsory schooling laws were undertaken simultaneously with other reforms. When compulsory schooling was raised to nine years, some German states also moved the start of the school year to early summer (cf Pischke, 2007). This implied the introduction of two short school years so that affected cohorts did in fact nominally complete 
9 instead of 8 grades although they spent only one third of a complete school year longer in school compared to the previous cohorts unaffected by the reform. It is hard to assess how much more these cohorts learnt in comparison to previous cohorts. But potentially we underestimate the effect of the increase in compulsory schooling if we do not take this transient shortening of the school year into account, and our estimates would then be interpreted as lower bounds of the true effect. We address this problem thoroughly in our section on robustness checks.

\section{Data and Descriptive Statistics}

The data used in our study are taken from five years of the German Microcensus $(1989,1995,1999,2002$, and 2003). The Microcensus is an annual, representative survey of one per cent of the households in Germany. Participation in the Microcensus is mandatory. However, the questions on health and health-related behavior are voluntary and are asked of a 45 percent random subsample only. The data contain, for each individual, sex and age, highest school degree and the current state of residence. In our analysis, we include cohorts born between 1930 and 1960 and currently living in the ten former West German states (excluding Berlin). We further restrict our analytical sample to individuals of German nationality and exclude individuals from the sample who have received their highest school degree in the former German Democratic Republic. Questions on health status (long-term illness and workrelated disability), available only in the 2002 survey, were asked of working age individuals (16-65 years). We thus need to restrict our analysis to cohorts born between 1937 and 1960 when using the 2002 data on health status. We further exclude all individuals living in Hamburg from the 2002 survey since the change in compulsory schooling laws there first affected cohorts born in 1934 and thus there is no exogenous variation in schooling.

Direct information on years in school as such is not available in the Microcensus. But the data provide the highest secondary school degree attained by each respondent. We use this information, together with both the number of years usually taken to obtain a certain degree and the compulsory schooling laws in the respective state, to impute years of schooling in each state, cohort and secondary school type. A dummy variable indicating whether the compulsory schooling laws require 8 or 9 years of schooling will serve as an instrument for an individual's years of schooling. Individuals without any school degree are either assigned 8 or 9 years of schooling depending on the compulsory schooling laws in effect. Since geographical information is limited to state of residence at the time of the survey, we need to 
assume that a person has attended school in his state of residence. This raises concerns about the validity of the results of our analysis which we will address in a robustness check.

We measure health and health-related behavior of the respondents by a number of variables. Current health is measured by an indicator variable whether someone suffers from long-term illness (we do not have information on specific diagnoses) and whether this illness limits the type or amount of work they can do (work disability). As mentioned above, this information is only available in 2002 and only for working age individuals. Another measure of current health is the body mass index (BMI), derived from self-reported information on weight and height in the 1999 and 2003 surveys. We used BMI to construct two dummy variables indicating overweight (BMI greater than 25) and obesity (BMI greater than 30). Note that our definition of overweight includes obesity. Also note that BMI, overweight or obesity can also be interpreted as indicators of future health because they are significant riskfactors for future health problems, e.g. diabetes or cardiovascular disease. We measure health behavior by information on smoking. In 1989, 1995, 1999, and 2003, individuals were asked whether they were smoking currently and, if not, whether they had ever smoked. We use this information to identify quitters. Information on number of cigarettes smoked is only reported in rather broad bands. Analyses based on this measure delivers qualitatively similar results compared to our results using just binary information on smoking status. We generally pool all survey years which contain the same dependent variables, because each survey year represents an independent random sample.

$$
\text { --- about here Table } 2 \text { (data description) --- }
$$

Descriptive statistics are presented in Table 2. There are roughly 25,000 individuals per sex in the 2002 "current health" sample. These individuals were born between 1937 and 1960 and were on average 52 to 53 years old in 2002. Mean years in school were 9.6 years for men and 9.4 years for women. $20 \%$ of men and $15 \%$ of women were suffering from a long term illness. $17 \%$ of men and $13 \%$ of women suffered from a long-term illness that limited the amount or type of work they could do, i.e. they were work disabled. In the "BMI sample", interviewed in 1999 and 2003, there are about 50,000 observations per sex. Average BMI was 26.7 for men and 25.3 for women. $66 \%$ of men were overweight or obese compared to only $44 \%$ of women. Obesity rates were $16 \%$ for men and $13 \%$ for women. These sex differences can also be seen when looking at the kernel density estimates (Figure 1) showing that the distribution is shifted to the right for men. For both sexes, one can see that a lot of the 
probability mass is concentrated in the BMI region around 25. For men, it even peaks at around those values.

\section{---about here Figure 1---}

For the analysis of smoking behavior, we have the largest samples with more than 120,000 observations for each sex. Overall, $63 \%$ of men and $39 \%$ of women reported having ever smoked. Current smoking rates are $36 \%$ for men and $24 \%$ for women. This implies that $44 \%$ of men (38\% of women) in our sample who ever smoked have stopped smoking.

--- about here Table 3 (distribution of leaving certificates) ---

Table 3 shows the proportion of individuals in the birth cohorts 1930,1940,1950, and 1960 who graduated from each of the three secondary school tracks. These data clearly show the educational expansion in West Germany after the Second World War. More than three quarters of the population born in 1930 received at most basic track schooling. This proportion has decreased to less than 50\% among those born in 1960. Moreover, the decline was much larger for women than for men. Both intermediate and academic track education has increased correspondingly. As a consequence, there is substantial variation across birth cohorts and states with respect to mean years of schooling (see Table 3 for cohorts and Figure 2 for selected states).

\section{---about here Figure 2---}

Figure 2 shows upward trends in average years of levels for four selected Western German states (graphs for other states look very similar), from values below 9 years for the 1930 birth cohorts to values above 10 years for the 1960 birth cohorts. In addition to those time trends for the whole period, one can also see jump of about 0.6 years in mean years of schooling at the time the change in mandatory schooling laws took effect. There are some more noteworthy points in Figure 2. For instance, Lower-Saxony and North Rhine-Westphalia were very much on the same "expansion path" until Lower-Saxony lengthened the basic track, and North Rhine-Westphalia caught up after prolonging mandatory schooling 6 years later. Further, the pictures illustrate the need to control for state-specific trends, as for example Schleswig-Holstein has a flatter increase in average educational attainment than BadenWuerttemberg (and other states). In our basic specification, we will thus control for statespecific linear trends in addition to (common) time fixed effects to control for these different paths of the educational expansion across states. 


\section{Empirical strategy}

We estimate both OLS and IV models. The former are estimated for descriptive purposes while the latter are given a causal interpretation. All equations are estimated for men and women separately and with robust standard errors which are clustered by state and year of birth. Our OLS model linking the health outcome to an individual's years of schooling is specified as:

$$
H_{i}=\beta_{0}+\beta_{1} S_{i}+\beta_{2} \text { age } e^{2}+\left(\text { cohort }{ }^{*} \text { state }\right)^{\prime} \delta+\mu_{\text {state }}+v_{\text {cohort }}+\eta_{\text {survey }}+\varepsilon_{i}
$$

where $H_{i}$ is a variable indicating some health outcome for individual $i$. $S_{i}$ denotes individual $i$ 's years of schooling. $\mu_{\text {state }}, v_{\text {cohort }}$ and $\eta_{\text {survey }}$ are sets of fixed effects accounting for heterogeneity between federal states, birth cohorts and survey years. In addition, we add linear cohort-state interaction effects controlling for differential trends across states. Note that we cannot include a linear age effect because it is perfectly collinear with cohort and survey year combined. Yet we are able to include quadratic age term in order to address potentially non-linear age effect. When using the 2002 wave only, the survey-specific fixed effects and the quadratic in age are excluded from the right-hand side of equation (1).

The method of instrumental variables - using changes in compulsory schooling laws discussed above as instruments - allows dealing with the potential endogeneity of education in equation (1) and thus allows estimating a causal effect of education on health and healthrelated behavior. Our identification rests on the assumption that - conditional on covariates compulsory schooling laws or changes therein are uncorrelated with health outcomes and health behaviors, except through their effect via education. Technically, we assume that state education policies are independent of any unobserved determinants of health in the second stage (health) equation.

One particular concern is that state-specific trends in health or health behavior may be correlated with both the change in compulsory schooling laws and unobserved characteristics of the individuals that are themselves health determinants. If this was the case, the association between the instrument and the health outcome would not only be due to the association between the instrument and years of schooling. For example, there may be macroeconomic factors such as higher per capita growth which positively affect both the income of (parental) households and a state's resources which are available for reforms of the schooling system (such as financing one more school year for more than half of each cohort). If schools are financed by income taxes, there might also be a negative contemporaneous correlation between net parental household income and education expenses. In any case, as long as 
parental household income affects health (Case, Lubotsky \& Paxson 2002, Reinhold \& Jürges 2009), state-specific trends in economic development may compromise the validity condition. For this reason, we estimate the IV-model controlling for state-specific linear trends. These trends should also capture effects of other measures of public policy which might be implemented together with the change in compulsory schooling laws. In additional robustness checks, we also investigate the robustness of our results to the inclusion of state-specific quadratic and cubic trends.

We estimate the following first stage equation:

$$
\mathrm{S}_{\mathrm{i}}=\gamma_{0}+\gamma_{1} Z_{\mathrm{i}}+\gamma_{2} \text { age }^{2}+\left(\text { cohort* }^{*} \text { state }\right)^{\prime} \kappa+\rho_{\text {state }}+\tau_{\text {cohort }}+\lambda_{\text {survey }}+v_{\mathrm{i}}
$$

where $S_{i}$ denotes again years of schooling. $Z_{i}$ is an instrumental variable indicating whether compulsory schooling laws require individual $i$ to stay at least 8 or 9 years in school. When constructing the schooling variable $\mathrm{S}_{\mathrm{i}}$, we assigned 8 or 9 years of schooling to the basic track according to the applicable compulsory schooling laws. Thus, the association between the instrumental variable and the schooling variable $\left(\gamma_{1}\right)$ arises by construction. $\rho_{\text {state }}, \tau_{\text {cohort }}$ and $\lambda_{\text {survey }}$ are sets of fixed effects accounting for heterogeneity between federal states, birth cohorts and survey years. Inserting years of schooling predicted from equation (2), $\hat{\mathrm{S}}_{\mathrm{i}}$, into equation (1) yields the second stage equation:

$$
\mathrm{H}_{\mathrm{i}}=\beta_{0}+\beta_{1} \hat{\mathrm{S}}_{\mathrm{i}}+\beta_{2} \text { age }^{2}+(\text { cohort*state })^{\prime} \delta+\mu_{\text {state }}+v_{\text {cohort }}+\eta_{\text {survey }}+\varepsilon_{\mathrm{i}},
$$

When using the 2002 wave only, the survey-specific fixed effects and the quadratic in age are excluded from the right-hand side of equations (2) and (3).

There are two concerns about the interpretation of our parameter of interest $\beta_{1}$ in equation (3). First, it is possible that the change in factual school attendance has not occurred sharply when a $9^{\text {th }}$ grade of compulsory schooling was introduced (see Pischke and von Wachter (2005) for a discussion). As a consequence, years of schooling may be overstated for some students in the basic track shortly after the introduction of the $9^{\text {th }}$ grade. This kind of one-sided measurement error would induce an attenuation bias even in IV-estimates so that our results have to be interpreted as lower bounds. We partly address this problem by analyzing the effects of short school years affecting some of the cohorts immediately after the raise of compulsory schooling in an additional robustness check.

Second, to allow for heterogeneous effects of education on health, we need to assume monotonicity, i.e. we need to rule out that after the lengthening of mandatory schooling some students decide to go to school shorter than they would without the reform (i.e. we assume 
that there are no "defiers"). In our case it seems plausible to assume that individuals with already high educational attainment (in intermediate or academic track) do not get less schooling because the mandatory years in basic track are raised by one year. This assumption would be violated if individuals chose a less demanding track or dropped out of school in reaction to the raise in years of compulsory schooling. We assess in a further robustness check whether this scenario is plausible. With heterogeneous causal effects and when the monotonicity assumption holds, we identify the effect of education only on compliers, i.e. individuals whose number of years in school is affected positively by the reform (Angrist and Imbens, 1995), which also includes individuals who decide to stay longer than the mandatory 9 years. Moreover, since the number of years in school is a multi-valued treatment, the IV estimates are equal to a weighted average of all complier-specific causal effects.

\section{Results}

\subsection{OLS results}

Long-term illness and work disability. OLS regression results are shown in Table 4. The OLS coefficients indicate a significant association between current health and education in both sexes. It is, however, stronger for men than for women. One more year in school is linked with a reduction in the likelihood of suffering from a long-term illness of 2.9 percentage points for men but only 1.2 percentage points for women. The association between years of schooling and long term illness is of substantive relevance considering that the overall prevalence rate of long term illness is $20 \%$ for men and $15 \%$ for women. The association between years in school and the probability of being work disabled is very pronounced and significant for both sexes, and it has about the same magnitude as the association of schooling and long-term illness.

\section{--- about here Table 4 (OLS results) ---}

BMI, overweight and obesity. The OLS estimates also indicate a significant association between years in school and body weight. Here, the association is much stronger for women than for men. One more year in school is linked with a decrease in BMI of 0.27 $\mathrm{kg} / \mathrm{m}^{2}$ for men and $0.47 \mathrm{~kg} / \mathrm{m}^{2}$ for women. In terms of overweight and obesity this means that each additional year in school is linked with a 3.1 (1.8) percentage point lower probability of being overweight (obese) for men, and a 4.7 (2.0) percentage point lower probability of being overweight (obese) for women. Again, these are fairly strong associations. 
Smoking. Smoking behavior is also strongly related to schooling, but more so for men than for women. The OLS estimates show that one more year of schooling is linked with a 2.6 percentage point lower proportion of men who ever smoked but only a 0.5 percentage point lower proportion of women who ever smoked. With respect to current smoking, the estimates suggest that one more year of schooling is associated with a decrease in the likelihood of being a smoker of 3.2 percentage points for men and of 2.1 percentage points for women. Further, the OLS estimates suggest a stronger association between years of schooling and the probability of quitting smoking for women than for men. One more year of schooling is associated with an increase in the probability of having quitted smoking of 4.1 percentage points among women and of 2.7 percentage points among men.

\subsection{Instrumental variables results}

Table 5 shows the relevant first and second stage coefficients from our IV estimation. As indicated by the first stage results, mandatory schooling laws have high explanatory power with respect to years of schooling. The introduction of a compulsory $9^{\text {th }}$ grade leads to an average increase of about 0.6 years in school. We use the Kleibergen-Paap weak identification test to assess the strength of our instruments. All test statistics are above 157 giving no rise to concerns about weak instrument problems. ${ }^{2}$ It is also interesting to investigate for whom we identify the effect of education on health. Following Acemoglu and Angrist (2000), we estimate the average causal response weights, i.e. the weight different complier groups contribute to our estimate. Not surprisingly, we find that these weights are concentrated on individuals having nine years of schooling (96.5\%) and much less weight on individuals with 10 years of schooling $(2.3 \%)$ or even higher levels of schooling $(1.2 \%)$. Thus, we largely identify an effect for individuals in the basic track getting nine instead eight years of schooling.

--- about here Table 5 (IV results) ---

Long-term illness and work disability. IV estimates of the effect of schooling on health outcomes differ substantially between men and women. For men, we find a large and significant causal effect of years of schooling on health. Our results indicate that one more year of schooling reduces the likelihood of suffering from a long term illness by 4.1

\footnotetext{
${ }^{2}$ It has to be taken into account that the German Microcensus does not contain a direct measure of years of schooling. Since we assigned 8 or 9 years of schooling to the basic track according to the applicable compulsory schooling laws, the strong association between the instrumental variable and the schooling variable arises largely by construction.
} 
percentage points for men (5\% significance level). Furthermore, the estimates for men suggest that one more year of schooling leads to a reduction in the likelihood of work disability 3.2 percentage points, which is close to the OLS result. In contrast to men, women appear not to gain from more schooling in terms of current health. The IV coefficients for women now have a positive sign but have become insignificant.

One possible explanation for the difference between men and women in the effect of education on work disability is that men with low levels of education tend to work more often in sectors where hard physical labor is performed, in particular in those older cohorts where labor force participation of women was much lower. For this reason, an additional year of schooling could be of particular relevance for the working conditions of men if it pushes men from blue to white collar jobs. Education is associated with non-manual labor occupations where dangers to physical health through exposure to injury, dangerous chemicals or adverse ergonomic conditions are reduced (WHO 2003). Furthermore, it could be the case that an individual with given health problems, as for instance back problems, would be able to work in a white-collar job but not in a blue-collar job anymore. If this was the case, we would also expect more cases of work disability for blue-collar workers. To investigate this hypothesis further, we included a set of occupational dummy variables in our regressions for long-term illness or work disability. ${ }^{3}$ We found that the size of the coefficient on years of schooling was reduced by roughly $25 \%$ for men (detailed results not shown). Part of the education effect on health thus seems to work through occupational choice. We also found that the effect of education on working in a white-collar job was smaller for women than for men. Therefore, it seems that gender differences in the effect of education on long term illness and work disability can partly be explained through the choice of occupational sector.

$B M I$, overweight, and obesity. For men's BMI, we find a significant effect of about the same size as the OLS results. One more year in school decreases male BMI by $0.3 \mathrm{~kg} / \mathrm{m}^{2}$. Among women, the effect approximately halves in size and becomes insignificant. Each year in school significantly reduces the probability of being overweight by 3.0 percentage points for men and 3.1 percentage points for women. Our effect sizes are consistent with the estimates for BMI in Pischke and von Wachter (2008, Table 3) who find a reduced form coefficient on mandatory schooling laws of $-0.16 \mathrm{~kg} / \mathrm{m}^{2}$ in the pooled sample of men and women. The relatively small effect on BMI and the strong effect on overweight can be explained by the fact that a lot of the density mass is concentrated right around the critical

\footnotetext{
${ }^{3}$ Note that we did not include occupational dummies in our main regressions because occupation is itself determined by education.
} 
threshold of a BMI of 25 (see Figure 1). The effect size is again in the range of the OLS coefficients for men but somewhat smaller for women. With respect to obesity, we obtain significant IV coefficients only for men but not for women.

Smoking behavior. In contrast to our health outcome measures and in contrast to the corresponding OLS results, our IV estimates do not suggest any significant effect of education on smoking behavior. This holds for having ever smoked, being a current smoker, and for having quitted smoking and for both sexes. With one exception, the IV coefficients have become much smaller than the OLS estimates and some coefficients even change signs. We checked whether the effect of education on smoking behavior is so different from the other health variables studied here because the data come from a longer and on average earlier period by restricting the sample to the survey years 1999 and 2003. IV estimates remained essentially zero.

\section{Robustness Checks}

We now address several concerns regarding our empirical strategy as mentioned before. First, we only have information on the current state of residence, but not on the state in which the individual has finished schooling. We thus restrict our sample to four contiguous states that have changed mandatory schooling laws at the same time. Second, we relax our assumption that the secular trends in health in Western Germany can be captured by (a common) cohort fixed effects plus a linear state-specific trends by estimating models adding also quadratic and cubic state-specific trends. Third, we investigate whether the mandatory schooling reforms had additional effects on track choice and dropping out behavior - as explained below this will give us some idea about the plausibility of the monotonicity assumption. And fourth, concurrent with raising compulsory schooling to nine years, the start of the school year was shifted from Easter to the end of summer in all German states. This was done by introducing short school years reducing the time spent in school by up to two thirds of a school year in some states (cf. Pischke, 2007). We account for this problem by recoding our endogenous variable years of schooling accordingly.

\subsection{Restricting the sample to four contiguous states}

A major concern about the validity of our results stems from the fact that geographical information is limited to state of residence at the time of the survey. Thus, we have to assume 
that a person has attended school in his current state of residence when constructing the instrumental variable as well as the schooling variable. This introduces a measurement error in both the instrument and the endogenous regressor, schooling. This is one source of attenuation bias discussed in Pischke and von Wachter $(2005,2008)$. We address this concern here by restricting our sample to four contiguous states that have reformed mandatory schooling simultaneously (see Figure 3).

\section{--- about here Figure 3 (Map) ---}

Baden-Wuerttemberg, Rhineland-Palatinate, Hesse, and North Rhine-Westphalia introduced the $9^{\text {th }}$ grade of compulsory schooling in 1967. In 1970, these four states represented $57 \%$ of the West German population. Since they do not border on a city state and contain large cities themselves, migration between the four states and other German states should be a minor issue. Furthermore, migration occurring within those four states does not matter since the $9^{\text {th }}$ grade has been introduced in the same year. In a first step, we analyzed the same birth cohorts as previously (1930-1960), simply restricting our sample to the four contiguous states. When restricting the sample we obtain qualitatively very similar results compared to the whole sample (detailed results not shown), indicating that attenuation bias due to migration between the states is not a major driver of our results.

The effect of the reform can in some sense be more satisfactorily estimated if we restrict our analysis to cohorts who are just affected and just not affected by the introduction of the $9^{\text {th }}$ year of compulsory schooling in the basic track. Including birth cohorts born between 1930 and 1960 was useful in the original analysis (including all federal states) because school reforms were dispersed over a larger time period. The downside is that one might be concerned about the ability to adequately capture the time trends even in the fairly flexible specification that we use. In the four-state sample, we can further restrict the sample to cohorts to the last cohort for whom the change in compulsory schooling laws was not yet applicable and the first cohort who was supposed to attend 9 years of schooling in the basic track. One problem with this approach, however, is that for those four states the raise in compulsory schooling laws takes place at the same time as the move of the start of the school year to the summer. This rescheduling was done by introducing short school years. While completing nine grades instead of eight the cohorts immediately affected by this rescheduling spent only around 8 and a third years in school which is not much more than the previous cohorts. We address this question separately below. In any case, we can interpret our coefficient estimates as a lower bound for the effect of an additional school year. 
Our identification rests on the assumption that cohorts just before and just after the reform took effect are very similar and differ only with respect to the treatment. In this case, we do not rely on estimating unobserved trends on the state level. In other words, we assume that the potential no-treatment outcomes of the two cohorts are identical. Technically, this means that we set cohort fixed effects to zero. We thus modify our IV estimation approach as follows: The first stage equation becomes:

$$
\mathrm{S}_{\mathrm{i}}=\gamma_{0}+\gamma_{1} \mathrm{Z}_{\mathrm{i}}+\gamma_{2} \text { age }+\gamma_{3} \mathrm{age}^{2}+\rho_{\text {state }}+\lambda_{\text {survey }}+v_{\mathrm{i}}
$$

The cohort-specific fixed-effects have been excluded from the right-hand side of equation (2). On the other hand, a linear age effect has now been included since it is not captured anymore by cohort-specific and survey-specific fixed effects.

The second stage equation becomes:

$$
\mathrm{H}_{\mathrm{i}}=\beta_{0}+\beta_{1} \hat{\mathrm{S}}_{\mathrm{i}}+\beta_{2} \text { age }+\beta_{3} \text { age }^{2}+\mu_{\text {state }}+\eta_{\text {survey }}+\varepsilon_{\mathrm{i}}
$$

When we estimate the effect on health outcomes that are only present in a single survey year of the German Microcensus, the survey-specific fixed effects, the linear age effect and the quadratic in age are excluded from the right-hand side of equations (4) and (5). The results are shown in Table 6. Because of the low number of clusters, we do not use clustered standard errors in the restricted sample but rely on conventional heteroskedasticity-robust standard errors.

--- about here Table 6 (robustness check) ---

The IV estimates for the restricted sample largely support our earlier findings - even though there are some differences. Naturally, the estimates are less precisely estimated when using the restricted sample. The estimated effect of education on long-term illness and work disability among men has increased substantially compared to the estimates for the unrestricted sample. For women, the point estimates have turned negative but they remain statistically insignificant. We also find substantially larger effects of years in school on BMI. Compared to the point estimates in the full sample the effects have more than doubled in size for men. For women they have more than tripled. Statistical significance is weak, however, which may be a results of the small size of the restricted sample. Similarly, despite substantially larger point estimates, we find a statistically significant effect of years in school on the probability of being overweight or obese only for women - which is in contrast to our results for the unrestricted sample. 
Finally, considering smoking behavior, most effects remain insignificant although there are some changes with respect to the effect sizes. However, we find a significant effect of years of schooling on the probability of ever having smoked for women (at the $10 \%$ significance level) suggesting that among women, one more year of schooling causes a decrease in the probability of ever having smoked of 6.4 percentage points. Compared to the prevalence rate of $52.4 \%$ in the restricted sample, the estimated effect is relatively large.

\subsection{Allowing for more flexible state-specific trends}

We now analyze whether controlling for state-specific linear cohort trends in addition to (common) cohort fixed effects is sufficient to control for unobserved trends at the state level which might be correlated with health and with the decision to institute mandatory schooling laws. one becomes more comfortable with the results. We present additional results including state specific quadratic or cubic trends in Table 7.

--- about here Table 7 (flexible state-specific trends)---

These results indicate that for men our results are very robust to the inclusion of more flexible state-specific trends. For long-term illness and work disability the coefficients maintain their significance levels and even slightly increase in size indicating a strong protective effect of education for men. For women, however, we still find basically a zero effect for long-term illness and work disability. These results are mirrored for BMI, and the probabilities of being overweight or obese. For men, the coefficients on education do not change much as one models the state-specific trends more flexible. However, for women, we now find a zero effect on weight problems. For smoking, we still do not find any significant results. These robustness checks suggest that there is only weak evidence for a causal effect of education for women's health in our sample when using our instrument (weak meaning it relies on more restrictive assumptions). However, our findings for men are strengthened.

\subsection{Track Choice and Drop out}

Next, we investigate whether the mandatory schooling reforms had additional effects on track choice and dropping out behavior. The sign of such effects is ex ante unclear. As shown previously, our instruments mainly identify the effect of schooling for individuals who acquire now 9 instead of 8 years of schooling. One crucial assumption in models with treatment effect heterogeneity is monotonicity, i.e. that all individuals react to the instruments 
in the same way (Angrist and Imbens, 1995). To be more concrete, this implies that individuals always prefer more education, e.g. they prefer 10 years of schooling (in intermediate track) to 9 years (in basic track) to 8 years (in basic track). Extending the basic track by one year would push students in basic track with such preferences from 8 to 9 years but leave the choices of intermediate track students unaffected. We would also observe no change in the leaving certificate. Whereas "defiers" in the strict sense that the reform pushes students from 9 to 8 years of schooling cannot exist by definition, there is still a possibility that students obtain less schooling as a consequence of the reform. Some individuals might prefer 9 years of schooling (in basic track) to 10 years (in intermediate track) to 8 years (in basic track). Prolonging basic track by one year would push these individuals from 10 back to 9 years of schooling and also changes the school leaving certificate. Yet other students possibly do not complete school, i.e. although they stay one year longer, they might leave without a certificate. Therefore, it would be reassuring if we found no effect of compulsory schooling laws on track choice, or that students attend a more demanding track in reaction to compulsory schooling laws, and no effect on "drop-out" rates. ${ }^{4}$

Another reason to look at track choice is to assess the potential role of peer effects. For instance, Jürges, Reinhold, and Salm (2009) look at the construction of new academic track schools increasing years of schooling mainly by increasing the proportion of students attending academic track schools. These shifts, however, also change the composition of students within the different school tracks. If we found only small effects of changes in compulsory schooling in basic track on track choice then the reforms would also likely not affect the composition of peers in the different school tracks.

To investigate track choice, we created a new dummy for students who graduated from the middle or academic track, and regressed this dummy on the same explanatory variables as in the previous analysis and compulsory schooling (detailed results available upon request). We find that lengthening compulsory schooling by one year increased the probability of attending middle school or academic track by around 1.5 percentage points for women and 0.6 percentage points for men. Thus, the net effect is positive but small, especially for men. While we cannot exclude the possibility that some students chose a less demanding school track as a reaction to increased compulsory schooling, we believe this is a minor concern. The main effect of the compulsory schooling reform appears to be the increase in the length of

\footnotetext{
${ }^{4}$ Even if there are defiers of the described sort, we can at least argue that our estimates provide a lower bound estimate of the effect of education on health - assuming that causal effects of education on compliers and defiers have the same sign. Moreover, we can also reason that the latter group should be quantitatively unimportant compared to compliers, because they must come from the smaller group of intermediate track students.
} 
schooling for basic track students and not a big change in the student composition. Similarly, we created a dummy variable for leaving school without a degree and regressed this variable on all explanatory variables and compulsory schooling laws. The results are a bit more ambiguous. For men, we find that compulsory schooling laws decreased the likelihood of dropping out by around 0.25 percentage points (statistically significant on the $5 \%$ level), while for women we find a positive, albeit not significant effect of around 0.12 percentage points. Thus, compulsory schooling laws had not much of an effect on leaving school without certificate. If anything, fewer students leave without certificate. Again, this poses no problem for our analysis because in this case the monotonicity assumption is not violated.

\subsection{Confounding Effects of Short School Years}

Another potential problem of our analysis is that the increase in compulsory schooling was accompanied by the introduction of short school years in some German states (see Pischke, 2007 for a detailed description). In the years 1966-67 the start of the school year was shifted from Easter to the end of summer. All states except Bavaria, Hamburg, and WestBerlin introduced two short school years (of 8 months each) for students attending school at this time to accommodate the change in the schedule. Thus, although the first cohorts after the introduction of compulsory schooling have completed nine formal grades instead of eight, they have not spent much more time in the class room compared to the previous cohorts who were subject to eight (full) years of compulsory schooling. Bavaria did not introduce short school years because the school year already started in summer, and Hamburg and WestBerlin opted for one extra-long school year. The introduction of the short school years could affect our results because we possibly over-estimate the true extent of schooling of the affected cohorts. For this reason, we perform a robustness check by recoding our endogenous variable "years of schooling" taking into account actual time spent in school instead of highest grade completed. The results are shown in table $8 .^{5}$

---Table 8 (robustness check short school years) about here---

The results indicate that our estimates are not very sensitive to the exact definition of short school years. The result for smoking among women is an exception indicating that years of schooling increase the likelihood that women have ever smoked substantially. We can only speculate about the reason for this finding. Perhaps recoding the endogenous variable

\footnotetext{
${ }^{5}$ Notice that the number of observations is lower in this sample because for individuals born in 1960 we cannot know for sure how many short school years they were exposed to.
} 
increased the weight of states without short school years in our estimates. Note, however, that this effect is transitory, as there is no statistically significant effect on current smoking among women.

\section{Summary and Discussion}

The present paper contributes to the growing literature on identifying the causal link between education and health and health-related behavior. Economic theory has identified causal effects of education on health through several plausible channels: (a) education raises efficiency in health production; (b) education changes inputs into health production (through information) and thereby increases allocative efficiency; (c) education itself changes time preference (and thus inputs into health production) because schooling focuses students' attention on the future; (d) education has an indirect effect mediated through higher income, occupational status, better housing, or healthier environmental conditions.

Numerous studies have indeed documented a strong positive empirical association between education and health. Interpretation of this correlation as causal is difficult, however, because education is most likely an endogenous variable, for instances because unobserved "pre-treatment" variables such as time preferences or cognitive and social skills, possibly drive both education and health behavior, or because health at younger ages, e.g. in early childhood affects both educational achievement and later life health. Recent empirical work addresses causality issues head on using natural experiments such as exogenous changes in compulsory schooling laws for identification. Our paper is directly linked to this literature. Using data from several German Microcensuses, we exploit changes in years of compulsory schooling in West German federal states that took effect between 1949 and 1969 to estimate the causal effect of years in school on long-term illness, work disability, BMI (and overweight/obesity) and current and former smoking measured in 1989 to 2003.

We find evidence for a strong and significant negative causal effect of years of schooling on long-term illness and work disability among men. Our IV estimates are slightly larger than OLS but in contrast to some of the existing literature they tend to be in the same range. For women, however, we do not find any significant causal effects on health status. A possible explanation for this finding is that women with low levels of education are less likely to perform hard physical labor than men. Additional analyses show that the effect of education on long-term health and work disability for men seems to be partly mediated through its effect on the probability of being a blue-collar worker. We also find some 
evidence for negative causal effects of education on male body weight and somewhat less convincing support for a negative effect on female body weight.

We also address some possible concerns about the validity of our results. One concern is that, because we only know individuals' current state of residence and not the state where they actually finished school, migration between the states results in measurement error in both the instrument and schooling. Our robustness check - exploiting that fact that four large contiguous states have lengthened compulsory schooling in the same year - suggests that migration is unlikely to compromise our estimation results. Further, we address the concern of unobserved state-specific trends which could be correlated with the instrument are biasing our results. In our most flexible specification, we allow for (common) cohort fixed effects and cubic state-specific cohort trends. These robustness checks do not alter our main conclusions. Next, we address the concern that changes in mandatory schooling laws could also affect the likelihood that a student leaves school without a degree or induces track changes that actually reduce the number of years in school. Such behavior would violate the monotonicity assumption made in the presence of heterogeneous treatment effects. Regression results indicate very small effects on track choice that are unlikely to threaten the validity of our main results. Finally, we allow for the fact that students affected by the mandatory schooling reform also underwent so-called short school years. Recoding our endogenous variable to account for short school years does not alter our results either.

In conclusion, the results or our paper can be put in the context of the existing theoretical and empirical literature as follows: based on our analysis, we can only partly distinguish between the four theoretical arguments for a causal effect of education on health mentioned above. A link via better health inputs in terms of less smoking is not supported by our data. ${ }^{6}$ Overweight and obesity can be interpreted not only as indicators of future health problems but also as indicators of past health behavior. Thus our findings on weight indirectly support the health input argument, although more so for men than for women. Again, changes in occupation from manual to non-manual could be an explanation. Further, we have not looked at income or wages in our paper. Considering existing evidence - using an identical identification strategy - changes in mandatory schooling had no causal effect on wages (Pischke \& von Wachter 2008), the link between education and health via higher income (and

\footnotetext{
${ }^{6}$ This is surprising because Jürges, Reinhold and Salm (2009) do find an effect of education on schooling using similar data using the construction of academic track schools as instruments. Possibly, these differences arise because they look at a different part of the schooling distribution and because in their set-up the composition of peers in the schools also changes as more students are drawn into academic track schools. We leave this question to further research.
} 
thus favorable living conditions) appears unlikely. Finally, it must also be noted that our parameters only identify the effect of education for compliers to the specific reforms of raising mandatory school leaving age. Interventions at other stages of the life-cycle or more specific interventions might have stronger and more systematic effects on health outcomes and health behavior. 


\section{References}

Acemoglu, D. and J. D. Angrist (2000): "How Large are the Social Returns to Education? Evidence from Compulsory Schooling Laws," In: National Bureau of Economics Macroeconomics Annual 2000. Editors: Ben S. Bernanke and Kenneth S. Rogoff. MIT Press Cambridge.

Albouy, V. and L. Lequien (2009): “ Does compulsory education lower mortality?”, Journal of Health Economics, Vol. 28, pp. 155-168.

Angrist, J. D. and G.W. Imbens (1995): “Two-stage least squares estimation of average causal effects in models with variable treatment intensity." Journal of the American Statistical Association, Vol. 90 (130), pp. 431-442.

Becker, G.S. and C.B. Mulligan (1997): The endogenous determination of time preference, Quarterly Journal of Economics 112, 729-758.

Carneiro, Pedro, Claire Crawford and Alissa Goodman (2007): The Impact of Early Cognitive and NonCognitive Skills on Later Outcomes. CEE DP 92. London School of Economics.

Case, A., D. Lubotsky, and C. Paxson (2002): "Economic Status and Health in Childhood: The Origins of the Gradient". American Economic Review, Vol. 92, No. 5, pp. 1308-1334

Clark, D. and H. Royer (2010): "The Effect of Education on Adult Mortality and Health: Evidence from the United Kingdom", NBER Working Paper 16013.

Cutler, David, and Adriana Lleras-Muney (2008): Education and Health: Evaluating theories and evidence. In: The effects of social and economic policy on health. Editors: J. Newhouse, R. Schoeni, G. Kaplan, and H. Polack, forthcoming, Russell Sage Press.

Cutler, David, and Adriana Lleras-Muney (2010): Understanding differences in health behaviors by education. Journal of Health Economics 29 (1), 1-28.

Deaton, A. (2002): Policy implications of the gradient of health and wealth, Health Affairs 21 (2), 13-30.

Deaton, A. (2003): Health, Income and Inequality. NBER Reporter, Spring 2003.

Deutsches Krebsforschungszentrum (2004): Rauchen und soziale Ungleichheit - Konsequenzen für die Tabakkontrollpolitik [Smoking and Health Inequality - Implications for tobacco control policy]. Heidelberg.

Dustmann, C. (2004): "Parental Background, Secondary School Track Choice, and Wages", Oxford Economic Papers, Vol. 56, pp. 209 - 230.

Fuchs, Victor (1982): Time Preference and Health: An Explanatory Study. pp. 93-120 in: VR Fuchs, Economic aspects of health, University of Chicago Press.

Grossman, Michael (1972), On the concept of health capital and the demand for health. Journal of Political Economy 80 (2), 223-255.

Grossman, Michael (2006), Education and non-market outcomes. In: Handbook of the Economics of Education, edited by: Eric Hanushek and Finis Welch, Elsevier Science.

Jürges, H. E. Kruk, and S. Reinhold (2009): The effect of compulsory schooling on health - evidence from biomarkers. Working Paper. University of Mannheim.

Jürges, H, S. Reinhold, and M. Salm (2009): "Does schooling affect health behavior? Evidence from the educational expansion in Germany," IZA discussion paper 4330.

Jürges, Hendrik and Kerstin Schneider (2007): " What can go wrong will go wrong: birthday effects and early tracking in the German school system. CESIfo Working Paper No. 2055.

Kenkel, Donald (1991): Health behavior, health knowledge, and schooling. Journal of Political Economy, 99, 287-305.

Lleras-Muney, A. (2005): "The Relationship between Education and Adult Mortality in the United States", Review of Economic Studies, Vol. 72, pp. 189-221.

Mokdad, Ali H, James S. Marks, Donna F. Stroup, and Julie F. Gerberding (2004): Actual causes of death in the United States, 2000. Journal of the American Medical Association, 291, 1238-1245.

Nayga, Rudolfo M. (2000): Schooling, health knowledge, and obesity. Applied Economics, 32, 815-832.

Oreopoulos, P. (2006): "Estimating average and local average treatment effects of education when compulsory schooling laws really matter," American Economic Review, Vol. 96 (1), pp. 152-175.

Pischke, J.-S. and T. von Wachter (2005): “Zero Returns to Compulsory Schooling in Germany: Evidence and Interpretation”, IZA Discussion Paper \#1645. 
Pischke, J.-S. (2007): "The Impact of Length of the School Year on Student Performance and Earnings: Evidence from The German Short School Years," Economic Journal, Vol. 117, pp. 1216-1242.

Pischke, J.-S. and T. von Wachter (2008): "Zero Returns to Compulsory Schooling in Germany: Evidence and Interpretation", The Review of Economics and Statistics, Vol. 90 (3), pp. 592-598.

Powdthavee, Nattavudh (2010): "Does Education Reduce the Risk of Hypertension? Estimating the Biomarker Effect of Compulsory Schooling in England". IZA Discussion Paper 4847.

Reinhold, S. and H. Jürges (2009): "Secondary school fees and the causal effect of schooling on health behavior." Health Economics, forthcoming.

Reinhold, S. and H. Jürges (2009b): "Parental Income and Child Health in Germany". MEA Discussion Paper 175-2009.

Riphahn, Regina (2008): The effect of secondary school fees on educational attainment. LASER Discussion Papers - Paper No. 21.

Rosenzweig, MR and Schulz. TP (1981): Education and Household Production of Child Health. In: Proceedings of the American Statistical Association (Social Statistics Section), 382-387.

Silles, M. (2009): "The Causal Effect of Education on Health: Evidence from the United Kingdom", Economics of Education Review 28 (1), 122-128.

De Walque, Damien (2007): Does education affect smoking behaviors? Evidence using the Vietnam draft as an instrument for college education, Journal of Health Economics, 26, 877-895.

World Health Organization (2003): Social determinants of health. The solid facts. $2^{\text {nd }}$ edition, http://www.euro.who.int/document/e81384.pdf, accessed March 16, 2010. 
Table 1 - Introduction of a 9th grade in the basic track of secondary school First year in which all students First birth cohort affected by the were supposed to graduate no change in compulsory schooling sooner than after nine years of laws compulsory schooling

\begin{tabular}{lcc}
\hline Hamburg & 1949 & 1934 \\
Schleswig-Holstein & 1956 & 1941 \\
Bremen & 1958 & 1943 \\
Lower Saxony & 1962 & 1947 \\
Saarland & 1964 & 1949 \\
North Rhine-Westphalia & 1967 & 1953 \\
Hesse & 1967 & 1953 \\
Rhineland-Palatinate & 1967 & 1953 \\
Baden-Wuerttemberg & 1967 & 1953 \\
Bavaria & 1969 & 1955 \\
\hline
\end{tabular}

Source: Pischke and von Wachter, 2005 
Table 2: Sample means (standard deviation in parentheses, number of observations below)

\begin{tabular}{|c|c|c|c|c|}
\hline Variable & Sex & $\begin{array}{c}\text { Microcensus } \\
\mathbf{2 0 0 2} \\
\text { Cohorts born } \\
\text { between } 1937 \text { and } \\
1960 \\
\end{array}$ & $\begin{array}{c}\text { Microcensus } \\
\mathbf{1 9 9 9 ,} \mathbf{2 0 0 3} \\
\text { Cohorts born } \\
\text { between } 1930 \text { and } \\
1960\end{array}$ & $\begin{array}{c}\text { Microcensus 1989, } \\
\text { 1995, 1999, } 2003 \\
\text { Cohorts born } \\
\text { between } 1930 \text { and } \\
1960 \\
\end{array}$ \\
\hline \multirow[t]{6}{*}{ Age } & Men & 52.48 & 54.76 & 50.13 \\
\hline & & $(7.10)$ & $(9.10)$ & $(10.27)$ \\
\hline & & 24,099 & 49,843 & 122,178 \\
\hline & Women & 52.63 & 55.19 & 50.57 \\
\hline & & $(7.11)$ & $(9.17)$ & $(10.31)$ \\
\hline & & 24,624 & 50,560 & 124,674 \\
\hline \multirow[t]{6}{*}{ Years in school } & Men & 9.63 & 9.50 & 9.42 \\
\hline & & $(1.82)$ & $(1.84)$ & $(1.80)$ \\
\hline & & 23,128 & 48,640 & 119,461 \\
\hline & Women & 9.39 & 9.20 & 9.17 \\
\hline & & $(1.62)$ & $(1.59)$ & $(1.55)$ \\
\hline & & 23,479 & 49,225 & 121,541 \\
\hline \multirow[t]{6}{*}{ Long-term illness } & Men & 0.20 & - & - \\
\hline & & $(0.40)$ & & \\
\hline & & 24,099 & & \\
\hline & Women & 0.15 & - & - \\
\hline & & $(0.36)$ & & \\
\hline & & 24,624 & & \\
\hline \multirow[t]{6}{*}{ Work disability } & Men & 0.17 & - & - \\
\hline & & $(0.37)$ & & \\
\hline & & 23,791 & & \\
\hline & Women & 0.13 & - & - \\
\hline & & $(0.33)$ & & \\
\hline & & 23,369 & & \\
\hline \multirow[t]{6}{*}{ BMI } & Men & - & 26.70 & - \\
\hline & & & $(3.66)$ & \\
\hline & & & 49,843 & \\
\hline & Women & - & 25.25 & - \\
\hline & & & $(4.36)$ & \\
\hline & & & 50,560 & \\
\hline \multirow[t]{6}{*}{ Overweight } & Men & - & 0.66 & - \\
\hline & & & $(0.47)$ & \\
\hline & & & 49,843 & \\
\hline & Women & - & 0.46 & - \\
\hline & & & $(0.50)$ & \\
\hline & & & 50,560 & \\
\hline \multirow[t]{6}{*}{ Obesity } & Men & - & 0.16 & - \\
\hline & & & $(0.36)$ & \\
\hline & & & 49,843 & \\
\hline & Women & - & 0.13 & - \\
\hline & & & $(0.34)$ & \\
\hline & & & 50,560 & \\
\hline \multirow[t]{6}{*}{ Ever smoked } & Men & - & - & 0.63 \\
\hline & & & & $(0.48)$ \\
\hline & & & & 122,178 \\
\hline & Women & - & - & 0.39 \\
\hline & & & & $(0.49)$ \\
\hline & & & & 124,674 \\
\hline \multirow[t]{6}{*}{ Currently smoking } & Men & - & - & 0.36 \\
\hline & & & & $(0.48)$ \\
\hline & & & & 122,178 \\
\hline & Women & - & - & 0.24 \\
\hline & & & & $(0.43)$ \\
\hline & & & & 124,674 \\
\hline \multirow[t]{6}{*}{ Quitted smoking } & Men & - & - & 0.44 \\
\hline & & & & $(0.50)$ \\
\hline & & & & 77,566 \\
\hline & Women & - & - & 0.38 \\
\hline & & & & $(0.49)$ \\
\hline & & & & 48,501 \\
\hline
\end{tabular}


Table 3: Distribution of leaving certificates in percent, by birth cohorts

\begin{tabular}{llllll}
\hline & & 1930 & 1940 & 1950 & 1960 \\
\hline Basic Track & Men & 76.8 & 69.1 & 58.8 & 47.7 \\
& Women & 82.1 & 73.0 & 63.0 & 40.7 \\
Intermediate & Men & 12.3 & 14.6 & 17.2 & 22.7 \\
& Women & 12.9 & 19.8 & 22.4 & 35.5 \\
Academic & Men & 10.9 & 16.3 & 23.9 & 29.6 \\
& Women & 4.9 & 7.2 & 14.6 & 23.8 \\
\hline
\end{tabular}


Table 4-OLS results

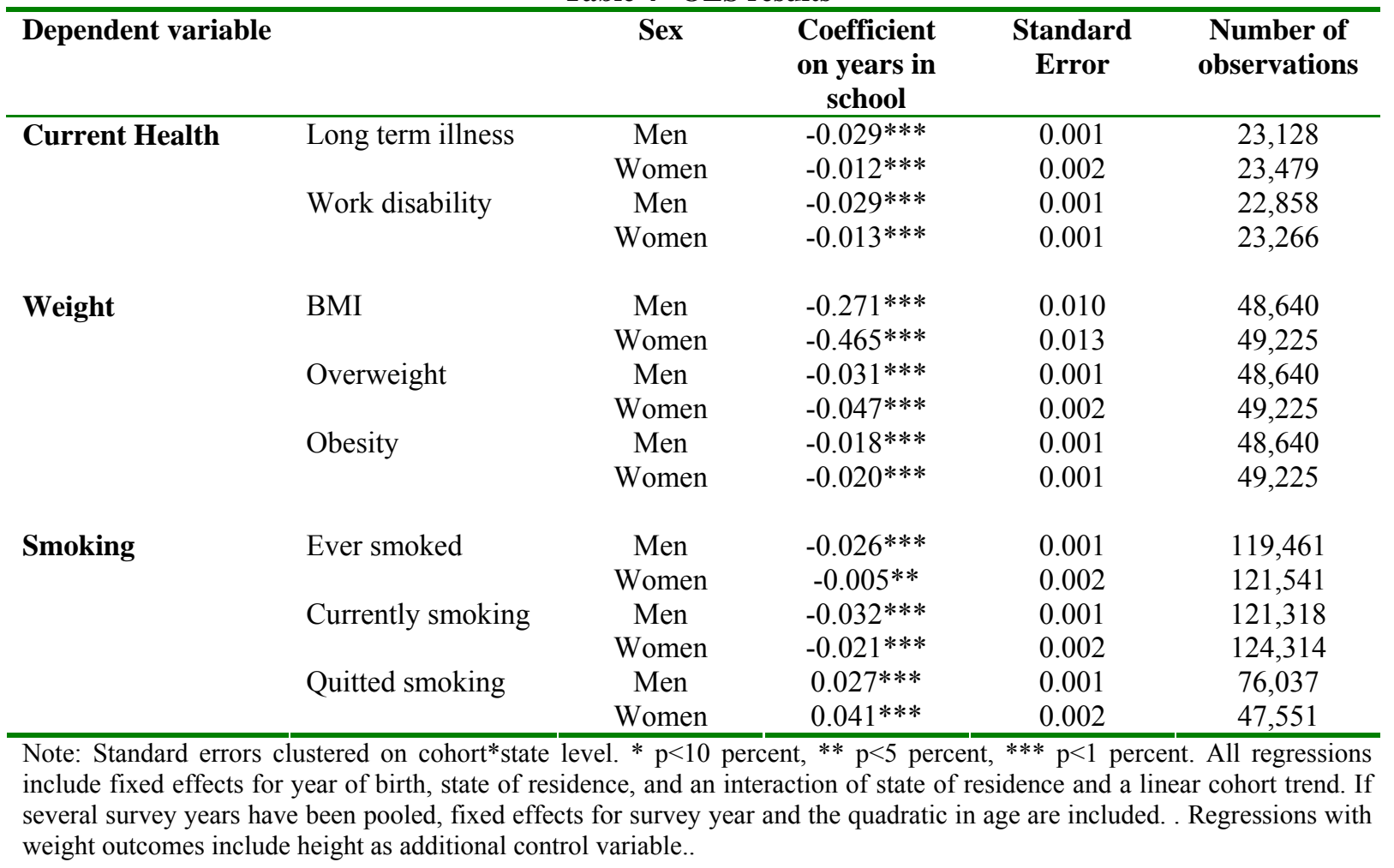


Table 5: Results of 2SLS regressions

\begin{tabular}{|c|c|c|c|c|c|}
\hline Dependent variable & & Sex & $\begin{array}{c}\text { First Stage } \\
\text { Coefficient on } \\
\text { instrument }\end{array}$ & $\begin{array}{c}\text { Second stage } \\
\text { coefficient on } \\
\text { years in school }\end{array}$ & $\begin{array}{c}\text { Number of } \\
\text { observations }\end{array}$ \\
\hline \multirow[t]{4}{*}{ Current Health } & Long term illness & Men & $\begin{array}{c}0.656^{* * * *} \\
(0.054) \\
160.3\end{array}$ & $\begin{array}{c}-0.041 * * \\
(0.017)\end{array}$ & 23,128 \\
\hline & & Women & $\begin{array}{c}0.579 * * * \\
(0.047) \\
161.8\end{array}$ & $\begin{array}{c}0.010 \\
(0.017)\end{array}$ & 23,479 \\
\hline & Work disability & Men & $\begin{array}{c}0.655 * * * \\
(0.055) \\
157.7\end{array}$ & $\begin{array}{c}-0.032 * * \\
(0.015)\end{array}$ & 22,858 \\
\hline & & Women & $\begin{array}{c}0.580 * * * \\
(0.047) \\
160.5\end{array}$ & $\begin{array}{c}0.021 \\
(0.016)\end{array}$ & 23,266 \\
\hline \multirow[t]{6}{*}{ Weight } & BMI & Men & $\begin{array}{c}0.595 * * * \\
(0.040) \\
238.0\end{array}$ & $\begin{array}{c}-0.301 * * \\
(0.121)\end{array}$ & 48,640 \\
\hline & & Women & $\begin{array}{c}0.663 * * * \\
(0.033) \\
380.2\end{array}$ & $\begin{array}{l}-0.194 \\
(0.133)\end{array}$ & 49,225 \\
\hline & Overweight & Men & $\begin{array}{c}0.595 * * * \\
(0.040) \\
238.0\end{array}$ & $\begin{array}{c}-0.030 * * \\
(0.015)\end{array}$ & 48,640 \\
\hline & & Women & $\begin{array}{c}0.663 * * * \\
(0.033) \\
380.2\end{array}$ & $\begin{array}{c}-0.031 * * \\
(0.015)\end{array}$ & 49,225 \\
\hline & Obesity & Men & $\begin{array}{c}0.595 * * * \\
(0.040) \\
238.0\end{array}$ & $\begin{array}{c}-0.030 * * \\
(0.014)\end{array}$ & 48,640 \\
\hline & & Women & $\begin{array}{c}0.663 * * * \\
(0.033) \\
380.2\end{array}$ & $\begin{array}{l}-0.004 \\
(0.010)\end{array}$ & 49,225 \\
\hline \multirow[t]{6}{*}{ Smoking } & Ever smoked & Men & $\begin{array}{c}0.615 * * * \\
(0.025) \\
620.8\end{array}$ & $\begin{array}{l}-0.011 \\
(0.011)\end{array}$ & 119,461 \\
\hline & & Women & $\begin{array}{c}0.655 * * * \\
(0.021) \\
952.3\end{array}$ & $\begin{array}{c}0.010 \\
(0.010)\end{array}$ & 121,541 \\
\hline & Currently smoking & Men & $\begin{array}{c}0.616^{* * * *} \\
(0.025) \\
631.5\end{array}$ & $\begin{array}{l}-0.005 \\
(0.010)\end{array}$ & 121,318 \\
\hline & & Women & $\begin{array}{c}0.654 * * * \\
(0.021) \\
975.1\end{array}$ & $\begin{array}{l}-0.001 \\
(0.009)\end{array}$ & 124,314 \\
\hline & Quitted smoking & Men & $\begin{array}{c}0.668 * * * \\
(0.030) \\
536.2\end{array}$ & $\begin{array}{l}-0.005 \\
(0.011)\end{array}$ & 76,037 \\
\hline & & Women & $\begin{array}{c}0.690 * * * \\
(0.031) \\
507.8\end{array}$ & $\begin{array}{c}0.015 \\
(0.012)\end{array}$ & 47,551 \\
\hline
\end{tabular}

Note: Clustered standard errors (on cohort*state level) in parentheses. In addition, we report Kleibergen-Paap rK Wald F statistics in italics. All regressions include fixed effects for year of birth, state of residence, and an interaction of state of residence and a linear cohort trend. If several survey years have been pooled, fixed effects for survey year and the quadratic in age are included. . Regressions with weight outcomes include height as additional control variable. ${ }^{*} \mathrm{p}<10$ percent, ${ }^{* *} \mathrm{p}<5$ percent, $* * * \mathrm{p}<1$ percent. 
Table 6: Robustness check (sample restricted to Baden-Wuerttemberg, Rhinland-Palatinate, Hesse and Northrhine-Westphalia)

\begin{tabular}{|c|c|c|c|c|c|c|}
\hline \multicolumn{2}{|c|}{ Dependent variable } & \multirow{2}{*}{$\begin{array}{l}\text { Sex } \\
\text { Men }\end{array}$} & \multirow{2}{*}{$\begin{array}{c}\text { OLS } \\
\\
-0.028 * * * \\
(0.006)\end{array}$} & \multirow{2}{*}{$\begin{array}{c}\text { 2SLS } \\
\text { First stage } \\
0.589 * * * \\
(0.111)\end{array}$} & \multirow{2}{*}{$\begin{array}{c}\text { 2SLS } \\
\text { Second } \\
\text { Stage } \\
-0.081 * * \\
(0.037)\end{array}$} & \multirow{2}{*}{$\begin{array}{c}\text { N obs. } \\
1,097\end{array}$} \\
\hline Current Health & Long-term illness & & & & & \\
\hline & & Women & $\begin{array}{c}-0.011^{*} \\
(0.006)\end{array}$ & $\begin{array}{c}0.716 * * * \\
(0.093)\end{array}$ & $\begin{array}{l}-0.013 \\
(0.028)\end{array}$ & 1,199 \\
\hline & Work disability & Men & $\begin{array}{c}-0.027 * * * \\
(0.005)\end{array}$ & $\begin{array}{c}0.592 * * * \\
(0.111)\end{array}$ & $\begin{array}{c}-0.074 * * \\
(0.034)\end{array}$ & 1,095 \\
\hline & & Women & $\begin{array}{c}-0.010^{*} \\
(0.005)\end{array}$ & $\begin{array}{c}0.721 * * * \\
(0.093)\end{array}$ & $\begin{array}{c}-0.014 \\
(0.025)\end{array}$ & 1,194 \\
\hline \multirow[t]{6}{*}{ Weight } & BMI & Men & $\begin{array}{c}-0.118^{* *} \\
(0.050)\end{array}$ & $\begin{array}{c}0.512 * * * \\
(0.125)\end{array}$ & $\begin{array}{l}-0.721 \\
(0.526)\end{array}$ & 1,874 \\
\hline & & Women & $\begin{array}{c}-0.412 * * * \\
(0.059)\end{array}$ & $\begin{array}{c}0.692 * * * \\
(0.114)\end{array}$ & $\begin{array}{c}-0.751^{*} \\
(0.438)\end{array}$ & 1,772 \\
\hline & Overweight & Men & $\begin{array}{c}-0.010^{*} \\
(0.006)\end{array}$ & $\begin{array}{c}0.512 * * * \\
(0.125)\end{array}$ & $\begin{array}{l}-0.061 \\
(0.067)\end{array}$ & 1,874 \\
\hline & & Women & $\begin{array}{c}-0.041 * * * \\
(0.007)\end{array}$ & $\begin{array}{c}0.692 * * * \\
(0.114)\end{array}$ & $\begin{array}{l}-0.064 \\
(0.048)\end{array}$ & 1,772 \\
\hline & Obesity & Men & $\begin{array}{c}-0.013 * * * \\
(0.004)\end{array}$ & $\begin{array}{c}0.512 * * * \\
(0.125)\end{array}$ & $\begin{array}{c}-0.020 \\
(0.049)\end{array}$ & 1,874 \\
\hline & & Women & $\begin{array}{c}-0.015 * * * \\
(0.004)\end{array}$ & $\begin{array}{c}0.692 * * * \\
(0.114)\end{array}$ & $\begin{array}{c}-0.072 * * \\
(0.032)\end{array}$ & 1,772 \\
\hline \multirow[t]{6}{*}{ Smoking } & Ever smoked & Men & $\begin{array}{c}-0.033 * * * \\
(0.004)\end{array}$ & $\begin{array}{c}0.507 * * * \\
(0.080)\end{array}$ & $\begin{array}{c}0.021 \\
(0.041)\end{array}$ & 4,525 \\
\hline & & Women & $\begin{array}{c}-0.018 * * * \\
(0.005)\end{array}$ & $\begin{array}{c}0.647 * * * \\
(0.069)\end{array}$ & $\begin{array}{l}-0.064 * \\
(0.034)\end{array}$ & 4,447 \\
\hline & Currently smoking & Men & $\begin{array}{c}-0.047 * * * \\
(0.004)\end{array}$ & $\begin{array}{c}0.512 * * * \\
(0.079)\end{array}$ & $\begin{array}{c}0.023 \\
(0.042)\end{array}$ & 4,585 \\
\hline & & Women & $\begin{array}{c}-0.036^{* * *} \\
(0.004)\end{array}$ & $\begin{array}{c}0.650 * * * \\
(0.069)\end{array}$ & $\begin{array}{l}-0.037 \\
(0.031)\end{array}$ & 4,513 \\
\hline & Quitted smoking & Men & $\begin{array}{c}0.041^{* * *} \\
(0.005)\end{array}$ & $\begin{array}{c}0.640 * * * \\
(0.092)\end{array}$ & $\begin{array}{c}-0.018 \\
(0.040)\end{array}$ & 3,029 \\
\hline & & Women & $\begin{array}{c}0.047 * * * \\
(0.006)\end{array}$ & $\begin{array}{c}0.677 * * * \\
(0.093)\end{array}$ & $\begin{array}{l}-0.009 \\
(0.042)\end{array}$ & 2,346 \\
\hline
\end{tabular}

Note: Robust standard errors in parentheses. All regressions include fixed effects for state of residence. If several survey years have been pooled, fixed effects for survey year and the quadratic in age are included. Regressions with weight outcomes include height as additional control variable. $* \mathrm{p}<10$ percent, $* * \mathrm{p}<5$ percent, $* * * \mathrm{p}<1$ percent 
Table 7: Robustness check (linear, quadratic, and cubic state-specific trends)

\begin{tabular}{|c|c|c|c|c|c|c|}
\hline \multicolumn{2}{|c|}{ Dependent variable } & \multirow{2}{*}{$\begin{array}{l}\text { Sex } \\
\text { Men }\end{array}$} & \multirow{2}{*}{$\begin{array}{c}\text { +linear } \\
\text { state trends } \\
-0.041^{* *} \\
(0.017)\end{array}$} & \multirow{2}{*}{$\begin{array}{c}\begin{array}{c}+ \text { quadratic } \\
\text { trends }\end{array} \\
-0.039 * * \\
(0.019)\end{array}$} & \multirow{2}{*}{$\begin{array}{c}\begin{array}{c}+ \text { cubic } \\
\text { trends }\end{array} \\
-0.045^{* *} \\
(0.018)\end{array}$} & \multirow{2}{*}{\begin{tabular}{|l} 
N obs. \\
23,128
\end{tabular}} \\
\hline Current Health & Long-term illness & & & & & \\
\hline & & Women & $\begin{array}{c}0.010 \\
(0.017)\end{array}$ & $\begin{array}{c}0.013 \\
(0.024)\end{array}$ & $\begin{array}{c}0.024 \\
(0.027)\end{array}$ & 23,479 \\
\hline & Work disability & Men & $\begin{array}{c}-0.032 * * \\
(0.015)\end{array}$ & $\begin{array}{c}-0.037 * * \\
(0.017)\end{array}$ & $\begin{array}{c}-0.045^{* * * *} \\
(0.017)\end{array}$ & 22,858 \\
\hline & & Women & $\begin{array}{c}0.021 \\
(0.016)\end{array}$ & $\begin{array}{c}0.036 \\
(0.022)\end{array}$ & $\begin{array}{c}0.040 \\
(0.025)\end{array}$ & 23,266 \\
\hline \multirow[t]{6}{*}{ Weight } & BMI & Men & $\begin{array}{c}-0.301 * * \\
(0.121)\end{array}$ & $\begin{array}{c}-0.306 * * \\
(0.136)\end{array}$ & $\begin{array}{c}-0.356 * * \\
(0.146)\end{array}$ & 48,640 \\
\hline & & Women & $\begin{array}{l}-0.194 \\
(0.133)\end{array}$ & $\begin{array}{l}-0.050 \\
(0.150)\end{array}$ & $\begin{array}{c}0.149 \\
(0.168)\end{array}$ & 49,225 \\
\hline & Overweight & Men & $\begin{array}{c}-0.030 * * \\
(0.015)\end{array}$ & $\begin{array}{c}-0.034 * * \\
(0.015)\end{array}$ & $\begin{array}{c}-0.039 * * \\
(0.016)\end{array}$ & 48,640 \\
\hline & & Women & $\begin{array}{c}-0.031 * * \\
(0.015)\end{array}$ & $\begin{array}{l}-0.016 \\
(0.016)\end{array}$ & $\begin{array}{l}-0.005 \\
(0.020)\end{array}$ & 49,225 \\
\hline & Obesity & Men & $\begin{array}{c}-0.030 * * \\
(0.014)\end{array}$ & $\begin{array}{l}-0.028^{*} \\
(0.015)\end{array}$ & $\begin{array}{l}-0.021 \\
(0.016)\end{array}$ & 48,640 \\
\hline & & Women & $\begin{array}{l}-0.004 \\
(0.010)\end{array}$ & $\begin{array}{c}0.007 \\
(0.012)\end{array}$ & $\begin{array}{l}0.023^{*} \\
(0.013)\end{array}$ & 49,225 \\
\hline \multirow[t]{6}{*}{ Smoking } & Ever smoked & Men & $\begin{array}{l}-0.011 \\
(0.011)\end{array}$ & $\begin{array}{l}-0.012 \\
(0.013)\end{array}$ & $\begin{array}{l}-0.004 \\
(0.014)\end{array}$ & 119,461 \\
\hline & & Women & $\begin{array}{c}0.010 \\
(0.010)\end{array}$ & $\begin{array}{c}0.014 \\
(0.011)\end{array}$ & $\begin{array}{c}0.015 \\
(0.011)\end{array}$ & 121,541 \\
\hline & Currently smoking & Men & $\begin{array}{l}-0.005 \\
(0.010)\end{array}$ & $\begin{array}{c}0.005 \\
(0.012)\end{array}$ & $\begin{array}{l}-0.001 \\
(0.014)\end{array}$ & 121,318 \\
\hline & & Women & $\begin{array}{l}-0.000 \\
(0.009)\end{array}$ & $\begin{array}{c}0.001 \\
(0.010)\end{array}$ & $\begin{array}{c}0.004 \\
(0.012)\end{array}$ & 124,314 \\
\hline & Quitted smoking & Men & $\begin{array}{l}-0.005 \\
(0.011)\end{array}$ & $\begin{array}{l}-0.019 \\
(0.013)\end{array}$ & $\begin{array}{l}-0.006 \\
(0.014)\end{array}$ & 76,037 \\
\hline & & Women & $\begin{array}{c}0.015 \\
(0.012)\end{array}$ & $\begin{array}{c}0.015 \\
(0.015)\end{array}$ & $\begin{array}{c}0.011 \\
(0.017)\end{array}$ & 47,551 \\
\hline
\end{tabular}

Note: Robust standard errors in parentheses. All regressions include fixed effects for state of residence. If several survey years have been pooled, fixed effects for survey year and the quadratic in age are included. Regressions with weight outcomes include height as additional control variable. ${ }^{*} \mathrm{p}<10$ percent, ${ }^{* *} \mathrm{p}<5$ percent, ${ }^{* * *} \mathrm{p}<1$ percent 
Table 8: Robustness Check with alternative definition of years of schooling taking into account short school years. Results of 2SLS regressions

\begin{tabular}{|c|c|c|c|c|c|}
\hline Dependent variable & & Sex & $\begin{array}{c}\text { First Stage } \\
\text { Coefficient on } \\
\text { instrument }\end{array}$ & $\begin{array}{l}\text { Second stage } \\
\text { coefficient on } \\
\text { years in school }\end{array}$ & $\begin{array}{c}\text { Number of } \\
\text { observations }\end{array}$ \\
\hline \multirow[t]{4}{*}{ Current Health } & Long term illness & Men & $\begin{array}{c}0.666^{* * * *} \\
(0.088) \\
122.65\end{array}$ & $\begin{array}{c}-0.066^{* * *} \\
(0.018)\end{array}$ & 19,824 \\
\hline & & Women & $\begin{array}{c}0.579 * * * \\
(0.096) \\
110.02\end{array}$ & $\begin{array}{c}0.006 \\
(0.017)\end{array}$ & 20,080 \\
\hline & Work disability & Men & $\begin{array}{c}0.664 * * * \\
(0.088) \\
120.19\end{array}$ & $\begin{array}{c}-0.054 * * * \\
(0.015)\end{array}$ & 19,578 \\
\hline & & Women & $\begin{array}{c}0.577 * * * \\
(0.096) \\
107.94\end{array}$ & $\begin{array}{c}0.015 \\
(0.016)\end{array}$ & 19,885 \\
\hline \multirow[t]{6}{*}{ Weight } & BMI & Men & $\begin{array}{c}0.591 * * * \\
(0.079) \\
176.49\end{array}$ & $\begin{array}{c}-0.429 * * * \\
(0.134)\end{array}$ & 43,509 \\
\hline & & Women & $\begin{array}{c}0.622 * * * \\
(0.075) \\
224.74\end{array}$ & $\begin{array}{l}-0.205 \\
(0.175)\end{array}$ & 43728 \\
\hline & Overweight & Men & $\begin{array}{c}0.591 * * * \\
(0.079) \\
176.49\end{array}$ & $\begin{array}{c}-0.046^{* * *} \\
(0.018)\end{array}$ & 43,509 \\
\hline & & Women & $\begin{array}{c}0.622 * * * \\
(0.075) \\
224.74\end{array}$ & $\begin{array}{l}-0.033 \\
(0.020)\end{array}$ & 43728 \\
\hline & Obesity & Men & $\begin{array}{c}0.591 * * * \\
(0.079) \\
176.49\end{array}$ & $\begin{array}{c}-0.036 * * \\
(0.014)\end{array}$ & 43,509 \\
\hline & & Women & $\begin{array}{c}0.622 * * * \\
(0.075) \\
224.74\end{array}$ & $\begin{array}{l}-0.004 \\
(0.012)\end{array}$ & 43728 \\
\hline \multirow[t]{6}{*}{ Smoking } & Ever smoked & Men & $\begin{array}{c}0.593 * * * \\
(0.076) \\
428.84\end{array}$ & $\begin{array}{l}-0.008 \\
(0.013)\end{array}$ & 106,532 \\
\hline & & Women & $\begin{array}{c}0.613 * * * \\
(0.071) \\
548.26\end{array}$ & $\begin{array}{c}0.027 * * \\
(0.013)\end{array}$ & 107,640 \\
\hline & Currently smoking & Men & $\begin{array}{c}0.595 * * * \\
(0.076) \\
437.03\end{array}$ & $\begin{array}{l}-0.009 \\
(0.013)\end{array}$ & 108,215 \\
\hline & & Women & $\begin{array}{c}0.613 * * * \\
(0.071) \\
563.55\end{array}$ & $\begin{array}{c}0.009 \\
(0.013)\end{array}$ & 110,186 \\
\hline & Quitted smoking & Men & $\begin{array}{c}0.638 * * * \\
(0.079) \\
353.71\end{array}$ & $\begin{array}{c}0.001 \\
(0.013)\end{array}$ & 67,467 \\
\hline & & Women & $\begin{array}{c}0.631 * * * \\
(0.071) \\
268.39\end{array}$ & $\begin{array}{c}0.017 \\
(0.016)\end{array}$ & 40,669 \\
\hline
\end{tabular}

Note Clustered standard errors (on cohort*state level) in parentheses. In addition, we report Kleibergen-Paap rK Wald F statistics in italics. All regressions include fixed effects for year of birth, state of residence, and an interaction of state of residence and a linear cohort trend. If several survey years have been pooled, fixed effects for survey year and the quadratic in age are included. . Regressions with weight outcomes include height as additional control variable. ${ }^{*} \mathrm{p}<10$ percent, ${ }^{* *} \mathrm{p}<5$ percent, $* * * \mathrm{p}<1$ percent. 


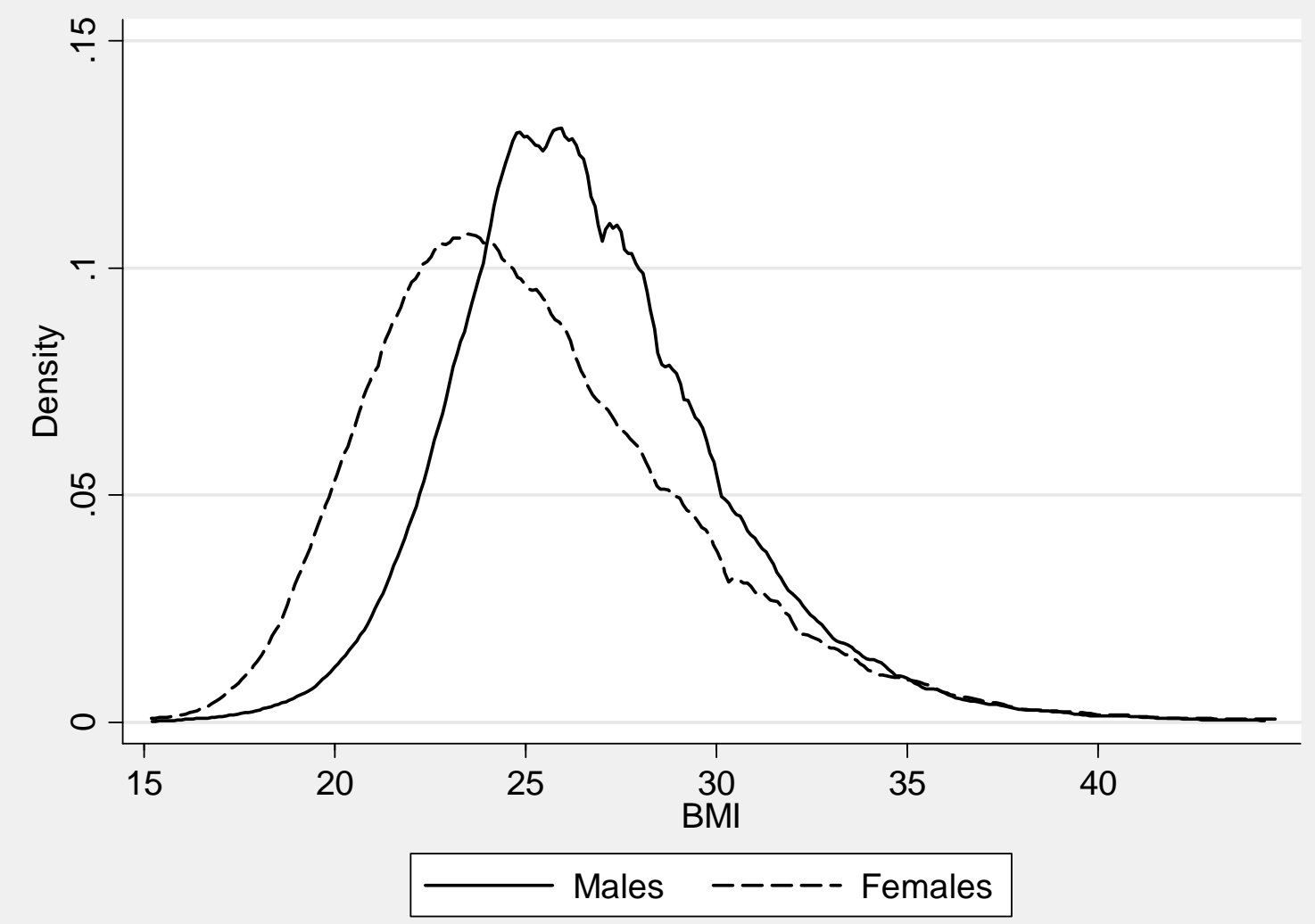

Figure 1: Kernel density estimate of BMI. 

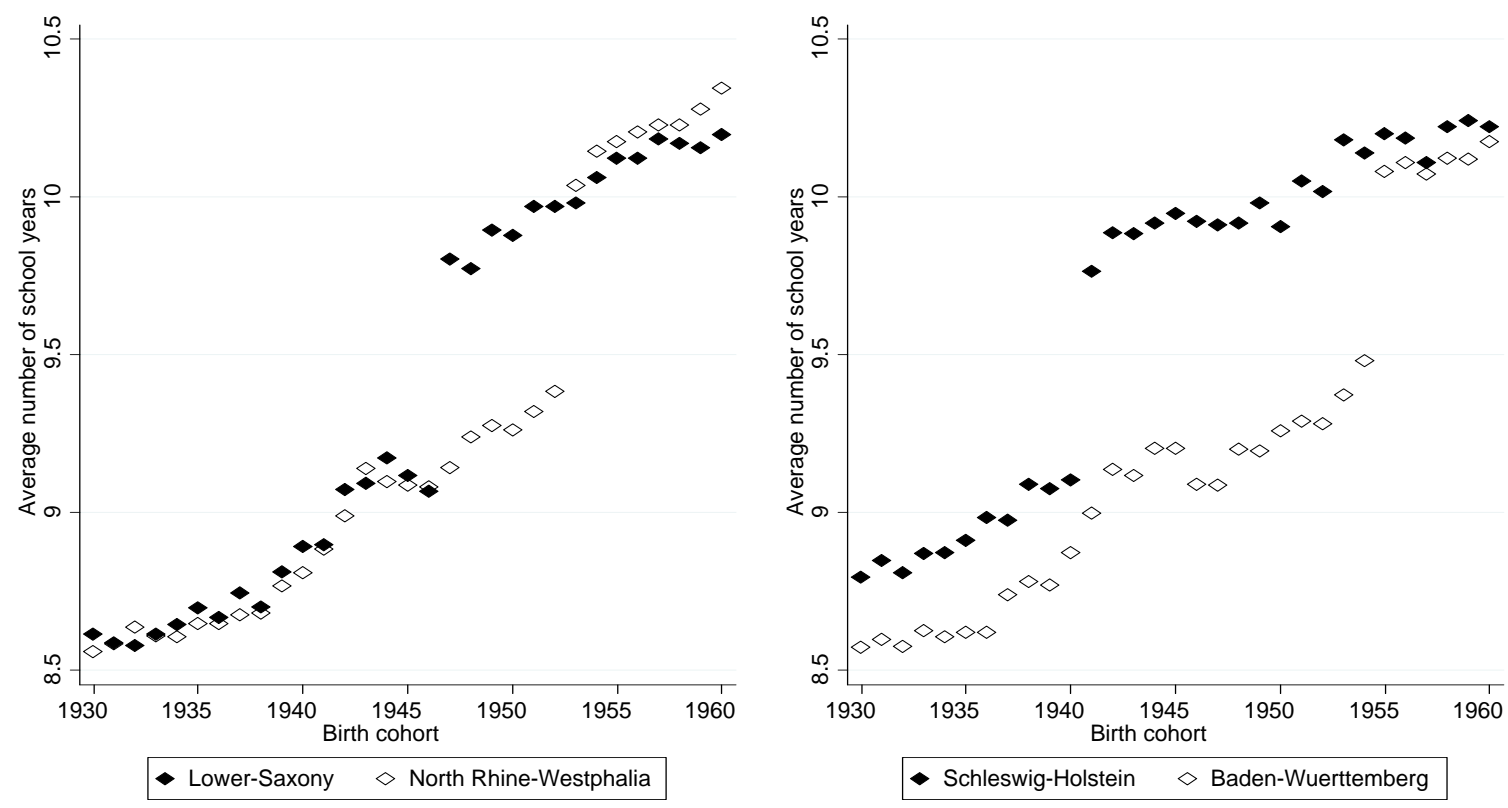

Figure 2: Mean number of years of schooling by birth cohort, selected federal states 


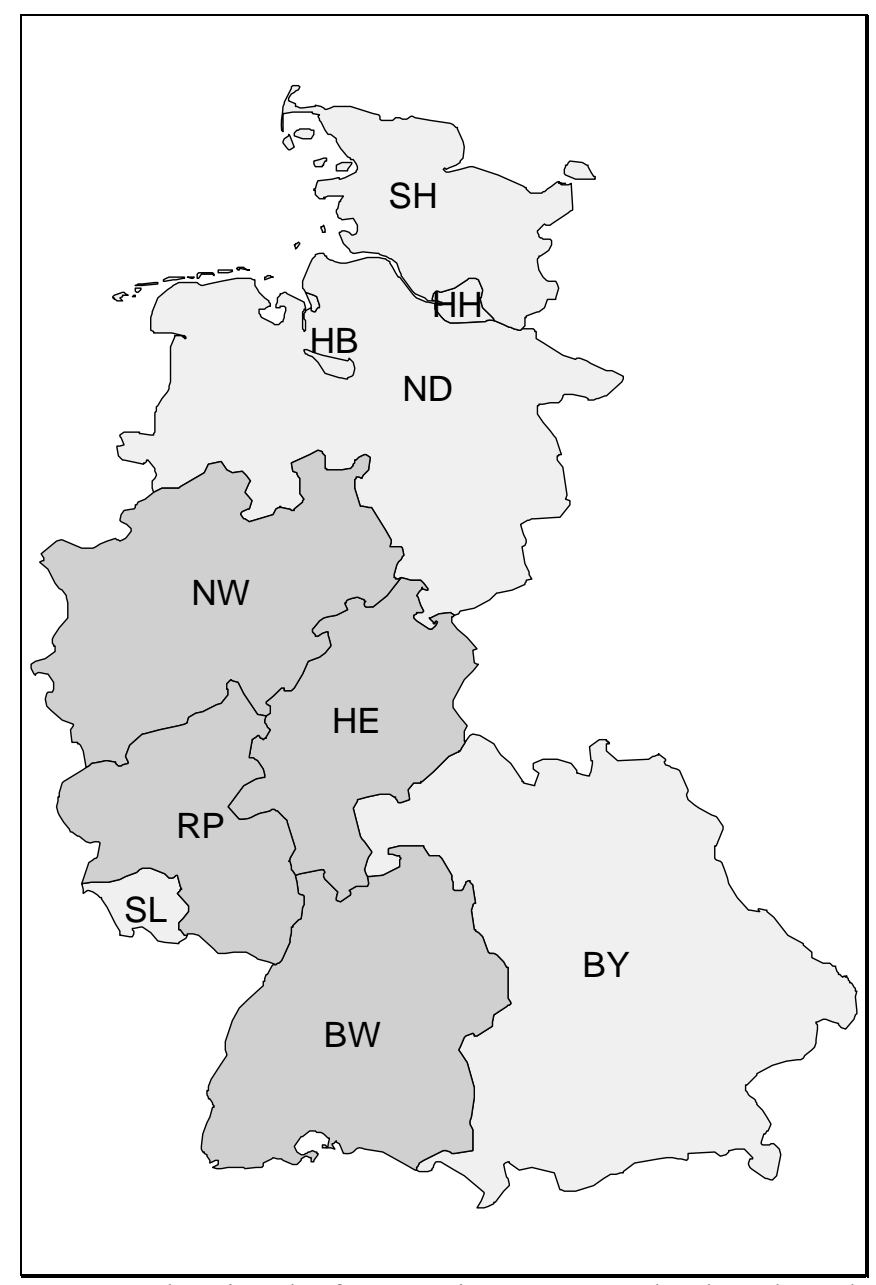

Figure 3: Map of West Germany showing the four contiguous states that lengthened compulsory schooling in the same year (NW=Northrhine-Westphalia, $\mathrm{HE}=$ Hesse, $\mathrm{RP}=$ Rhineland-Palatinate, $\mathrm{BW}=$ Baden-Wuerttemberg) 


\section{Discussion Paper Series}

Mannheim Research Institute for the Economics of Aging, Universität Mannheim

To order copies, please direct your request to the author of the title in question.

\begin{tabular}{|c|c|c|c|}
\hline Nr. & Autoren & Titel & Jahr \\
\hline $188-09$ & $\begin{array}{l}\text { Beatrice Scheubel, } \\
\text { Daniel Schunk, } \\
\text { Joachim Winter }\end{array}$ & $\begin{array}{l}\text { Don't raise the retirement age! An experiment } \\
\text { on opposition to pension reforms and East- } \\
\text { West differences in Germany }\end{array}$ & 09 \\
\hline $189-09$ & Martin Gasche & $\begin{array}{l}\text { Die sozialversicherungspflichtig Beschäftigten } \\
\text { im deutschen Sozialversicherungssystem: } \\
\text { Eigenschaften, Beitragsleistungen und } \\
\text { Leistungsbezug }\end{array}$ & 09 \\
\hline $190-09$ & Martin Gasche & $\begin{array}{l}\text { Implizite Besteuerung im deutschen } \\
\text { Sozialversicherungssystem }\end{array}$ & 09 \\
\hline 191-09 & $\begin{array}{l}\text { Alexander Ludwig, } \\
\text { Alexander Zimper }\end{array}$ & $\begin{array}{l}\text { Biased Bayesian learning and the risk-free } \\
\text { rate puzzle }\end{array}$ & 09 \\
\hline 192-09 & $\begin{array}{l}\text { Tabea Bucher- } \\
\text { Koenen }\end{array}$ & $\begin{array}{l}\text { Financial Literacy and Private Old-age } \\
\text { Provision in Germany - Evidence from SAVE } \\
2008 \text { - }\end{array}$ & 09 \\
\hline 193-09 & $\begin{array}{l}\text { Axel Börsch-Supan, } \\
\text { Martin Gasche, } \\
\text { Michael Ziegelmeyer }\end{array}$ & $\begin{array}{l}\text { Auswirkungen der Finanzkrise auf die private } \\
\text { Altersvorsorge }\end{array}$ & 09 \\
\hline 194-09 & Wolfgang Kuhle & The Optimum Structure for Government Debt & 09 \\
\hline 195-09 & $\begin{array}{l}\text { Michela Coppola, } \\
\text { Anette Reil-Held }\end{array}$ & $\begin{array}{l}\text { Dynamik der Riester-Rente: Ergebnisse aus } \\
\text { SAVE } 2003 \text { bis } 2008\end{array}$ & 09 \\
\hline $196-10$ & $\begin{array}{l}\text { Alexander Ludwig, } \\
\text { Thomas Schelkle, } \\
\text { Edgar Vogel }\end{array}$ & $\begin{array}{l}\text { Demographic Change, Human Capital and } \\
\text { Welfare }\end{array}$ & 10 \\
\hline $197-10$ & $\begin{array}{l}\text { Axel Börsch-Supan, } \\
\text { Martin Gasche }\end{array}$ & Zur Sinnhaftigkeit der Riester-Rente & 10 \\
\hline $198-10$ & $\begin{array}{l}\text { Martin Gasche, } \\
\text { Michael Ziegelmeyer }\end{array}$ & $\begin{array}{l}\text { Verbreitung der Riester-Rente - Hat die } \\
\text { Finanz- und Wirtschaftskrise Spuren } \\
\text { hinterlassen? }\end{array}$ & 10 \\
\hline $199-10$ & Martin Gasche & $\begin{array}{l}\text { Rentenanpassung } 2010 \text { - Wem nützt die } \\
\text { Rentengarantie? }\end{array}$ & 10 \\
\hline $200-10$ & $\begin{array}{l}\text { Daniel Kemptner, } \\
\text { Hendrik Jürges, } \\
\text { Steffen Reinhold }\end{array}$ & $\begin{array}{l}\text { Changes in Compulsory Schooling and the } \\
\text { Causal Effect of Education on Health: } \\
\text { Evidence from Germany }\end{array}$ & 10 \\
\hline
\end{tabular}

